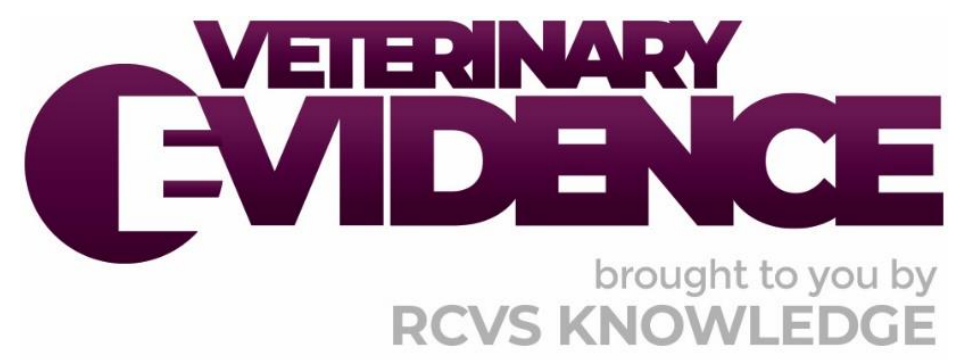

\title{
Is Topical or Systemic Antimicrobial Therapy More Effective for the Treatment of Feline Acne With Secondary Bacterial Infection?
}

\section{A Knowledge Summary by}

Wendy Kwok BVMS MSC MRCVS ${ }^{1 *}$

Kate Mellor BVMedSci BVM BVS MSc MRCVS²

\footnotetext{
${ }^{1}$ Jockey Club College of Veterinary Medicine and Life Sciences, City University of Hong Kong, Tat Chee Ave, Kowloon Tong, Hong Kong

${ }^{2}$ Royal Veterinary College, 4 Royal College St, London NW1 0TU

*Corresponding Author (wendy.kwok@cityu.edu.hk)
}

ISSN: 2396-9776

Published: 30 Aug 2018

in: Vol 3, Issue 3

DOI: http://dx.doi.org/10.18849/ve.v3i3.125

Reviewed by: Myra Forster-van Hijfte (CertVR CertSAM DipECVIMcA FRCVS) and Constance White (DVM, PhD)

Next Review Date: 30 Aug 2020 


\section{KNOWLEDGE SUMMARY}

\section{PICO question}

In cats with feline acne and secondary bacterial folliculitis or furunculosis, is topical or systemic antimicrobial therapy superior for reducing time to resolution and severity of clinical signs?

\section{Clinical bottom line}

There is no sufficient evidence to compare topical versus systemic treatment in feline acne with secondary folliculitis/furunculosis.

\section{Clinical scenario}

A five-year-old male neutered Persian indoor cat presents with crusting, comedones, erythema and alopecia of the chin. Deep skin scrapings are negative for ectoparasites and cytology of superficial scrapings shows intracellular cocci and neutrophils. The owner declines culture and sensitivity testing due to financial restrictions. Should the patient be treated with topical and/or systemic antimicrobials?

\section{The evidence}

Evidence found was made up of a prospective open-label trial and a retrospective descriptive study based on medical records, both with low ranking in the hierarchy of evidence. No randomised case-control studies or experimental studies comparing topical to systemic antimicrobial treatment were found.

\section{Summary of the evidence}

\begin{tabular}{|r|l|}
\hline \multicolumn{2}{|l|}{ White et al. (1997) } \\
\hline Population: & $\begin{array}{l}\text { Owned cats presenting to 5 veterinary dermatology referral centres } \\
\text { with a clinical diagnosis of feline acne (comedones, crusts and or } \\
\text { nodules on chin) and without any treatment in the month prior to } \\
\text { examination at referral }\end{array}$ \\
\hline Sample size: & $\begin{array}{l}25 \text { cats (mean 5.4 years, range 0.5-16 years, 10 male neutered, 3 male } \\
\text { entire, 8 female spayed, 4 female entire) }\end{array}$ \\
\hline Intervention details: & $\begin{array}{l}\text { Non-randomised treatment groups, owners of all cats instructed to } \\
\text { topically apply 2\% mupirocin ointment to chin lesions twice a day for } 3 \\
\text { weeks }\end{array}$ \\
\hline Study design: & Prospective open-label trial \\
\hline Outcome studied: & $\begin{array}{l}\text { Percentage of lesions resolved following topical treatment with 2\% } \\
\text { mupirocin and subjective scoring of the change of severity of lesions } \\
\text { remaining }\end{array}$ \\
\hline
\end{tabular}




\begin{tabular}{|c|c|}
\hline $\begin{array}{r}\text { Main findings: } \\
\text { (relevant to PICO question): }\end{array}$ & $\begin{array}{l}\text { - Response to treatment was graded from excellent }(90-100 \% \\
\text { resolution of clinical signs), good ( } 50-90 \% \text { resolution of clinical } \\
\text { signs) and fair (<50\% but some resolution noted) } \\
\text { - The severity of lesions in the study population was uncertain, as } \\
\text { criteria for severity such as the presence of draining tracts, severe } \\
\text { nodules or fistulae were not included in the grading system } \\
\text { - After three weeks of treatment, } 12 \text { of } 25 \text { cats were graded as } \\
\text { having an excellent response and of these, } 2 \text { resolved completely. } \\
\text { - The remaining } 12 \text { cats were graded as having a good response to } \\
\text { treatment. } \\
\text { Of the cats classed as having a good response, } 4 \text { received a further } \\
\text { three weeks of treatment. Of these, } 3 \text { had an excellent response } \\
\text { and } 1 \text { maintained a good response } \\
\text { The majority of cases were only evaluated at one time point after } \\
\text { three weeks of treatment, which is insufficient to evaluate duration } \\
\text { of treatment effect. Four cats were followed up again three weeks } \\
\text { later following an extended treatment course. }\end{array}$ \\
\hline
\end{tabular}

\begin{tabular}{|c|c|}
\hline Limitations: & $\begin{array}{l}\text { - } \quad \text { There was no explicit comparison of topical to systemic antibiotics } \\
\text { - } \quad \text { So systemic drugs were used in study } \\
\text { - } \quad \text { Recruitment of the cohort was not randomised, not controlled and } \\
\text { not necessarily representative of the population } \\
\text { - } \quad \text { No control group } \\
\text { - } \text { diagnosis of secondary bacterial infection } \\
\text { - } \text { limit bias (although the authors tried to maintain consistency by } \\
\text { having the same clinician evaluate cases before and after } \\
\text { - } \quad \text { Inteatment) } \\
\text { corroborater agreement was not measured and there was no } \\
\text { - Clinical severity of feline acne in the study population could not be } \\
\text { accurately assessed as there were no criteria for differentiating } \\
\text { between furunculosis and folliculitis included in the grading system } \\
\text { - Confounding factors include potential antifungal properties of } \\
\text { - } \text { mupirocin, which were discussed but not investigated } \\
\text { - Treatment of } 1 \text { cat was stopped due to contact dermatitis }\end{array}$ \\
\hline
\end{tabular}

Scott and Miller (2010)

\begin{tabular}{|r|l|}
\hline Population: & $\begin{array}{l}74 \text { feline patients with feline acne, 31 of which were diagnosed with } \\
\text { secondary bacterial folliculitis or furunculosis at Cornell University } \\
\text { Hospital for Animals between 1988-2003 }\end{array}$ \\
\hline Sample size: & $\begin{array}{l}31 \text { cats (female spayed } 54.1 \% \text {, male neutered } 35.1 \%, \text { female entire } \\
6.8 \%, \text { male entire } 4 \%)\end{array}$ \\
\hline Intervention details: & $\begin{array}{l}\text { Cats with a diagnosis of feline acne and secondary bacterial folliculitis } \\
\text { or furunculosis and were treated with systemic and/or topical }\end{array}$ \\
\hline
\end{tabular}




\begin{tabular}{|c|l|}
\hline & $\begin{array}{l}\text { antimicrobials. } \\
\text { Topical antibiotics used included benzoyl peroxide, chlorhexidine, } \\
\text { mupirocin } \\
\text { Systemic antibiotics used included amoxicillin clavulanate, cefadroxyl, } \\
\text { clindamycin, tylocin. } \\
\text { The numbers of cats receiving each treatment type were not specified. }\end{array}$ \\
\hline Study design: & Retrospective descriptive study based on medical records \\
\hline Outcome studied: & $\begin{array}{l}\text { Resolution of secondary bacterial infection } \\
\text { Follow up information (range: } 2 \text { months - 10 years) was evaluated for } \\
\text { (relevant to PICO question): } 31 \text { cats }\end{array}$ \\
\hline Main findings: & $\begin{array}{l}\text { All cats responded to antimicrobial therapy (but this was not } \\
\text { quantified or further described) }\end{array}$ \\
\hline $\begin{array}{l}\text { All cases responded to either topical or systemic treatment or a } \\
\text { combination of both }\end{array}$ & $\begin{array}{l}\text { All cats had persistent comedonal disease which remained post } \\
\text { treatment }\end{array}$ \\
\hline Only 2 cats were known to relapse and topical mupirocin was used \\
in these 2 cats for 2-4 years to prevent recurring infections. Dosage \\
was not specified by the authors.
\end{tabular}

\section{Appraisal, application and reflection}

The purpose of this Knowledge Summary was to evaluate whether topical or systemic antimicrobial treatment was more effective for reducing time to resolution and severity of clinical signs in feline acne patients with secondary bacterial infection.

No controlled clinical studies or experimental studies were found directly comparing the effect of topical to systemic antimicrobial treatment. The two studies found included no control groups. Both studies indicated positive response to treatment. However, both were low in the hierarchy of evidence and did not provide evidence to enable comparison of the use of topical, systemic or combined antimicrobial treatments. The prospective open-label trial evaluating the effect of topical $2 \%$ mupirocin for the treatment of bacterial folliculitis or furunculosis secondary to feline acne (White et al. 1997) indicates that this regimen reduces clinical signs by at least $50 \%$ for most treated cats immediately following a three-week treatment course. However, cases were not followed up further and may have required ongoing or recurrent treatment. Two of 25 cats had full resolution of clinical signs following three weeks of treatment. No control group was included, 
and consideration must be given to the potential for spontaneous resolution. The severity of lesions in the study population was uncertain, as criteria for severity such as the presence of draining tracts, severe nodules or fistulae were not included in the grading system. The study population may have had relatively mild feline acne for which topical $2 \%$ mupirocin treatment was sufficient to alleviate clinical signs. However, topical $2 \%$ mupirocin may or may not be as effective in patients with severe furunculosis. There was no comparison of topical and systemic antimicrobial treatments.

The retrospective descriptive study (Scott and Miller 2010) also did not compare topical and systemic antimicrobial treatments. No distinction was made between treatment groups. Cats with secondary bacterial folliculitis or furunculosis were successfully treated with systemic and/or topical antimicrobials. A good clinical response was not defined. However, comedones persisted in all cases even with resolution of secondary infection. Selection of treatment for cats may or may not have been influenced by disease severity and is unknown. Consequently, there is insufficient evidence to indicate resolution of moderate/severe clinical signs following treatment. Cats with more severe lesions may have been more likely to have received systemic or combined systemic and topical antimicrobial treatment. Therefore, there is insufficient evidence for comparison of the efficacy of these treatments.

In conclusion, topical $2 \%$ mupirocin ointment appears to be effective in the treatment of bacterial infection secondary to feline acne. However, the severity of cases was not graded and therefore can only provide evidence for efficacy of topical $2 \%$ mupirocin ointment for treatment of mild cases of feline acne with secondary bacterial infection. The strength of evidence was weak and this structured evidence review was therefore unable to draw firm conclusions. A high-quality randomised controlled trial is necessary to help answer this question.

\section{Methodology Section}

\begin{tabular}{|c|c|}
\hline \multicolumn{2}{|l|}{ Search Strategy } \\
\hline $\begin{array}{r}\text { Databases searched and dates } \\
\text { covered: }\end{array}$ & $\begin{array}{l}\text { CAB Abstracts (1973 - Week } 5 \text { 2017), PubMed (all years - Week } 23 \\
\text { 2017) }\end{array}$ \\
\hline Search terms: & $\begin{array}{l}\text { (cat or cats or feline or felines or felis) AND (Antibiotic or antibiotics } \\
\text { or antimicrobial or antimicrobials or anti-microbial or antimicrobials } \\
\text { or antibacterial or antibacterials or 'antiinfective agent' or } \\
\text { 'antiinfective agents' or 'anti-infective agent' or anti-infective } \\
\text { agents') AND ('feline pyoderma' or 'feline chin acne' or 'feline acne' } \\
\text { or 'chin acne' or 'bacterial pyoderma' or 'superficial pyoderma' or } \\
\text { 'bacterial folliculitis' or 'bacterial furunculosis') }\end{array}$ \\
\hline Dates searches performed: & $15^{\text {th }}$ February 2017 (CAB Abstracts) and $5^{\text {th }}$ June 2017 (PubMed) \\
\hline
\end{tabular}

Exclusion / Inclusion Criteria

Exclusion: Articles not available in English, articles not relevant to the question, duplicates

Inclusion: Articles in English and relevant to the question 


\begin{tabular}{|l|c|c|c|c|}
\hline \multicolumn{2}{|c|}{ Search Outcome } & Excluded - & Excluded - Not \\
\hline Database & Number of results & $\begin{array}{r}\text { non-English } \\
\text { language } \\
\text { publication } \\
\text { relevant to question }\end{array}$ & $\begin{array}{r}\text { Total relevant } \\
\text { papers }\end{array}$ \\
\hline CAB Abstracts & 84 & 18 & 64 & 2 \\
\hline NCBI PubMed & 26 & 1 & 25 & 0 \\
\hline Total relevant papers when duplicates removed & & 2 \\
\hline
\end{tabular}

\section{CONFLICT OF INTEREST}

The authors declare no conflict of interest.

\section{REFERENCES}

1. Scott, D.W., Miller, W.H. (2010) 'Feline Acne: A Retrospective Study of 74 Cases (1988-2003)', Japanese Journal of Veterinary Dermatology, 16(4), 203-209. DOI:

https://doi.org/10.2736/ijvd.16.203

2. White, S.D., Bordeau, P.B., Blumstein, P. et al., (1997) 'Feline acne and results of treatment with mupirocin in an open clinical trial: 25 cases (1994-96)', Veterinary Dermatology 8, 157-164. DOI: https://doi.org/10.1046/j.1365-3164.1997.d01-16.x 


\section{EVIIDEFeE

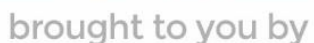 \\ RCVS KNOWLEDGE}

\section{Intellectual Property Rights}

Authors of Knowledge Summaries submitted to RCVS Knowledge for publication will retain copyright in their work, and will be required to grant RCVS Knowledge a non-exclusive license of the rights of copyright in the materials including but not limited to the right to publish, re-

publish, transmit, sell, distribute and otherwise use the materials in all languages and all media throughout the world, and to license or permit others to do so.

\section{Disclaimer}

Knowledge Summaries are a peer-reviewed article type which aims to answer a clinical question based on the best available current evidence. It does not override the responsibility

of the practitioner. Informed decisions should be made by considering such factors as individual clinical expertise and judgement along with patient's circumstances and owners' values. Knowledge Summaries are a resource to help inform and any opinions expressed within the Knowledge Summaries are the author's own and do not necessarily reflect the view of the RCVS Knowledge. Authors are responsible for the accuracy of the content. While the

Editor and Publisher believe that all content herein are in accord with current recommendations and practice at the time of publication, they accept no legal responsibility

for any errors or omissions, and make no warranty, express or implied, with respect to material contained within.

For further information please refer to our Terms of Use.

RCVS Knowledge is the independent charity associated with the Royal College of Veterinary Surgeons (RCVS). Our ambition is to become a global intermediary for evidence based veterinary knowledge by providing access to information

that is of immediate value to practicing veterinary professionals and directly contributes to evidence based clinical decision-making.

https://www.veterinaryevidence.org/

RCVS Knowledge is a registered Charity No. 230886.

Registered as a Company limited by guarantee in England and Wales No. 598443.

Registered Office: Belgravia House, 62-64 Horseferry Road, London SW1P 2AF

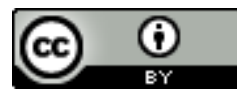

This work is licensed under a Creative Commons Attribution 4.0 International License 